\title{
Contribution of rumen protozoa to duodenal flow of nitrogen, conjugated linoleic acid and vaccenic acid in steers fed silages differing in their water-soluble carbohydrate content
}

\author{
David R. Yáñez-Ruiz ${ }^{1}$, Nigel D. Scollan ${ }^{2}$, Roger J. Merry ${ }^{2}$ and Charles J. Newbold ${ }^{1}$ \\ ${ }^{1}$ Institute of Rural Sciences, University of Wales Aberystwyth, Llanbadarn Campus, Aberystwyth SY23 3AL, UK \\ ${ }^{2}$ Institute of Grassland and Environmental Research, Plas Gogerddan, Aberystwyth SY23 3ED, UK
}

(Received 28 February 2006 - Revised 14 June 2006 - Accepted 16 June 2006)

\begin{abstract}
The present experiment was designed to estimate the quantitative contribution of rumen protozoa to the total N, conjugated linoleic acid (CLA) and vaccenic acid (VA; trans-11-18:1) flow to the duodenum of steers fed two silage diets: control silage (CS) and silage high in water-soluble carbohydrates (HS). Protozoal duodenal flows were estimated using a real-time PCR assay to quantify the genes encoding protozoal $18 \mathrm{~S}$ ribosomal RNA. Denaturing gradient gel electrophoresis was used to confirm that the rumen protozoa populations were similar to the protozoal population flowing to the duodenum. Estimated duodenal flow of protozoal $\mathrm{N}$ was 14.2 and $18.2 \mathrm{~g} / \mathrm{d}(P>0.05)$ for animals fed the CS and HS diets respectively. Protozoal flow thus represented between 12 and $15 \%$ of the total $\mathrm{N}$ duodenal flow. In terms of fatty acid flow, protozoa accounted for between 30 and $43 \%$ of the CLA and 40\% of the VA reaching the duodenum. The contribution of protozoa to 16:0 and 18:0 flows to the duodenum was less than 20 and $10 \%$, respectively. These results show that the fatty acids within protozoa make up a significant proportion of the CLA and VA reaching the duodenum of ruminants.
\end{abstract}

Conjugated linoleic acid: Protozoa: Rumen: Vaccenic acid: Water-soluble carbohydrates

Microbial cell matter that flows to the duodenum from the rumen is an important source of nutrients for the host animal. To date the contribution of microbial cell matter has been mainly considered in terms of $\mathrm{N}$ supply; however, microbial cells also account for a significant proportion of the fatty acids leaving the rumen. There is currently an increasing interest in the fatty acid composition of ruminant products, particularly in regards to conjugated linoleic acid (CLA). Food products derived from ruminant animals are the major source of CLA in human diets. The main form of CLA, cis-9, trans-11-18:2 ( $c 9, t 11-C L A)$, can be produced directly by microbial hydrogenation in the rumen or by a $\Delta^{9}$-desaturase in the animals' tissues, using vaccenic acid (VA; trans-11-18:1) formed in the rumen as its substrate (Bauman et al. 1999). The second most abundant isomer of CLA, trans-10, cis-12-18:2 (t10,c12-CLA) is also formed in the rumen. Some isomers of CLA have been associated with the inhibition of some types of cancer (De la Torre et al. 2005), reduction of atherosclerosis (Toomey et al. 2005), enhancement of the immune response (Zhang et al. 2005) and body fat repartitioning (Blankson et al. 2000). However, recently, some experiments on laboratory animals appear to suggest that the $t 10, c 12$-CLA isomer may have detrimental effects on health (Wahle et al. 2004).

To date the production of CLA and VA in the rumen has been considered solely from the perspective of bacterial metabolism and it has been suggested that protozoa are of minor importance (Harfoot \& Hazlewood, 1997). The role of ciliate protozoa in fatty acid biohydrogenation in the rumen remains unclear; Wright (1959) suggested that protozoa rapidly reduced trienes to dienes and monenes to saturated acids in vitro but the conversion of dienes to monoenes was slow. Abaza et al. (1975) found that mixed entiodinomorphs reduced oleic acid to stearic acid even in the presence of antibiotics. However, this was disputed by Singh \& Hawke (1979) who, using fractionated rumen contents incubated with ${ }^{14} \mathrm{C}$ labelled monogalactosyldiacylglycerol, suggested that the contribution made by protozoa to biohydrogenation was due to the activity of ingested bacteria. Recently, Devillard et al. (2004) have extended this observation to suggest that the CLA and VA content of rumen protozoal cells was 4-5-fold higher than found in bacteria, suggesting that protozoa may also represent a major pool of CLA and VA in the rumen.

It is, however, difficult to calculate what the contribution of protozoa to fatty acid supply at the duodenum would be, as it is clear from many studies that protozoa tend to be retained in the rumen and that outflow to the duodenum does not always reflect ruminal concentrations (Dehority, 2003). However, research into protozoal passage to the duodenum has been hindered by the lack of a suitable marker of protozoal flow (Firkins et al. 1998).

Recently, Sylvester et al. (2005) have re-examined this problem using an approach based on the use of real-time PCR,

Abbreviations: CLA, conjugated linoleic acid; $c 9, t 11-C L A$, cis-9, trans-11-18:2; t10,c12-CLA, trans-10, cis-12-18:2; CS, control silage; DGGE, denaturing gradient gel electrophoresis; HS, silage high in water-soluble carbohydrates; rDNA, ribosomal DNA; VA, vaccenic acid.

* Corresponding author: Dr David R. Yáñez-Ruiz, fax +44 1970 611264, email dyy@aber.ac.uk 
utilising primers specific to protozoal $18 \mathrm{~S}$ ribosomal DNA (rDNA), to quantify protozoa in duodenal digesta. In the present study we have taken advantage of a trial in which duodenal flows were measured in steers receiving diets based on silages containing different levels of water-soluble carbohydrate to apply the technique described by Sylvester et al. (2005) to access the protozoal contribution to the flow of N, CLA and VA reaching the duodenum.

\section{Materials and methods}

\section{Animals and experimental design}

Six Hereford $\times$ Friesian steers, initial live weight $173 \pm 7 \cdot 1 \mathrm{~kg}$, each prepared with a rumen cannula and simple ' $T$ '-piece cannulae in the proximal duodenum were used. They were housed in individual pens, and transferred to metabolism crates for the measurement period. The building was well ventilated and animals had free access to fresh water. A vitamin-mineral pre-mix (Rumins Cattle Regular; Rumenco Ltd, Burton-on-Trent, Staffs, UK) was offered at $100 \mathrm{~g} /$ head per d, sprinkled on the top of the morning meal. This pre-mix included: macro-minerals $\mathrm{Ca}, \mathrm{P}, \mathrm{Mg}$ and $\mathrm{Na}$ at 200, 40, 50 and $80 \mathrm{~g} / \mathrm{kg}$, respectively; micro-minerals $\mathrm{Se}, \mathrm{Co}, \mathrm{I}, \mathrm{Mn}, \mathrm{Zn}, \mathrm{Fe}$ and $\mathrm{Cu}$ at $0 \cdot 02,0 \cdot 15,0 \cdot 25,3 \cdot 5,3 \cdot 5,3 \cdot 0$ and $1.8 \mathrm{~g} / \mathrm{kg}$, respectively; vitamins (retinol, cholecalciferol and alphatocopherol at 90, 1.5 and $667 \mathrm{mg} / \mathrm{kg}$, respectively).

The experimental design was a two-period changeover, with two dietary treatments: control grass silage (CS) and highwater-soluble carbohydrates grass silage (HS), commercially named 'FEN' and 'AberDOVE', respectively. Each period consisted of $20 \mathrm{~d}$, consisting of $17 \mathrm{~d}$ adaptation to the diet, and $3 \mathrm{~d}$ for rumen and duodenal sampling. Silage was made from a second season cut on 6 September 2003 and wilted for $4 \mathrm{~h}$ before being baled using a round baler. A commercial silage inoculum was applied at the manufacturer's recommended rate at the time of ensilage (Ecosyl; Ecosyl Products Ltd, Stokesley, Cleveland, UK). All the silage for the trial was removed from the bales, mixed to obtain a homogeneous mix and then stored at $4^{\circ} \mathrm{C}$ until fed. Animals received their food ad libitum as two equal meals, at 09.00 and 16.00 hours. Refusals represented 6.34 to $9.31 \%$ and 5.37 to $8.88 \%$ of silage offered for periods 1 and 2, respectively.

\section{Experimental procedures and sample preparation}

Digesta flow was estimated using a dual-phase marker system with ytterbium acetate and Cr-EDTA as the particulate and liquid markers, respectively (Faichney, 1975). The markers (ytterbium acetate, $450 \mathrm{mg}$ Yb per d; Cr-EDTA, $3450 \mathrm{mg} \mathrm{Cr}$ per d) were infused continuously into the rumen using a peristaltic pump (202U; Watson-Marlow Ltd, Falmouth, Cornwall, UK) at a rate of $18 \mathrm{ml} / \mathrm{h}$ for $6 \mathrm{~d}$ before digesta sampling. On days 18 and 19 of the experiment, duodenal digesta $(300 \mathrm{ml})$ was collected every $3 \mathrm{~h}$ over a $24 \mathrm{~h}$ period and stored at $4{ }^{\circ} \mathrm{C}$. Accumulated samples of daily duodenal digesta were thoroughly mixed and a $200 \mathrm{~g}$ subsample representing whole digesta was freeze-dried. Another pooled subsample $(10 \mathrm{~g})$ was kept at $-80^{\circ} \mathrm{C}$ for DNA extraction. A separate $200 \mathrm{~g}$ portion of duodenal digesta was centrifuged at $3000 \mathrm{~g}$ for $25 \mathrm{~min}$ to provide a sample of solid digesta.
These were subsequently freeze-dried, ground and retained frozen for analysis. On day 20, samples of rumen content ( 2 litres) were collected $2 \mathrm{~h}$ after the first feeding time. A subsample $(250 \mathrm{ml})$ was used to isolate microbial cells by centrifuging at $3000 \mathrm{~g}$ for $25 \mathrm{~min}$, then the supernatant fraction was centrifuged at $30000 \mathrm{~g}$ for $25 \mathrm{~min}$ followed by a distilled water wash and a further spin $(30000 \mathrm{~g})$ repeated three times, to minimise contamination from whole rumen contents (Lee et al. 2002). The pellet was then freeze-dried before analysis. Another subsample $(5 \mathrm{ml})$ was treated with an equal volume of $18.5 \%(\mathrm{v} / \mathrm{v})$ formaldehyde for protozoa cell counting (Dehority, 1984). The rest of the rumen sample was filtered through two layers of cheesecloth; the dry particulate fraction was washed by hand with $39^{\circ} \mathrm{C}$ Coleman buffer (Williams \& Coleman, 1992) and added to the first filtrate to maximise the recovery of particulate-associated protozoa. Approximately $10 \mathrm{ml}$ was kept at $-80^{\circ} \mathrm{C}$ for DNA extraction and subsequent denaturing gradient gel electrophoresis (DGGE) analysis in order to compare rumen protozoal populations with the population recovered at the duodenum. The rest $(300 \mathrm{ml})$ was immediately used for isolation of washed protozoa as follows. The sample was diluted with $300 \mathrm{ml}$ Coleman buffer and placed in a separation funnel at $39^{\circ} \mathrm{C}$ and allowed to flocculate for $45 \mathrm{~min}$. The flocculent layer was aspirated and the bottom layer was drawn off and filtered through a nylon filter cloth with a $400 \mu \mathrm{m}$ pore size to remove the remaining plant material. The last filtrate was filtered through a new nylon filter cloth with a $10 \mu \mathrm{m}$ pore size to remove contaminating bacteria that were externally associated with protozoa. The retained protozoal cells were washed four more times ( $125 \mathrm{ml}$ each time) with Coleman buffer in each washing to ensure minimal bacterial contamination. A sample of the protozoal solution obtained after each filtration step was taken and kept at $-80^{\circ} \mathrm{C}$ for DNA extraction to monitor bacterial contamination by real-time PCR. The final protozoal solution obtained from each animal was split into two subsamples; one kept at $-80^{\circ} \mathrm{C}$ for DNA extraction and the other kept at $-20^{\circ} \mathrm{C}$. Samples of protozoal solutions and duodenal contents kept at $-20^{\circ} \mathrm{C}$ were freeze-dried and ground to pass a $0.5 \mathrm{~mm}^{2}$ screen before fatty acid analysis.

\section{Molecular analyses}

DNA was extracted from frozen protozoal solutions and duodenal samples using the QIAamp ${ }^{\circledR}$ DNA Stool Mini Kit (Qiagen Ltd, Crawley, West Sussex, UK) following the manufacturer's instructions. DNA concentrations in isolated protozoal solutions were determined using BisBenziminde (Labarca \& Paigen, 1980), in order to use them as standards for the real-time PCR assay.

\section{Denaturing gradient gel electrophoresis analysis}

DGGE was used to compare protozoal diversity between rumen and duodenum samples for each experimental animal. In addition, rumen protozoal sample profiles were also compared with the protozoal preparation obtained by filtering to check whether the protozoal population in the standards represents those in the rumen.

Approximately $400 \mathrm{bp}$ of the $18 \mathrm{~S}$ rDNA gene was amplified using rumen ciliate-specific primers (Regensbogenova 
et al. 2004): forward -5'-GGTGGTGCATGGCCG-3'; reverse -AATTGCAAAGATCTATCCC with a forty-fivenucleotide GC-clamp linked to the $5^{\prime}$ terminus of the reverse primer. The primers were designed to be specific to the rumen ciliates using derived sequence information (Moonvan der Staay et al. 2002). PCR was performed using the following steps: one cycle $\left(94^{\circ} \mathrm{C}\right.$ for $\left.4 \mathrm{~min}\right)$; thirty cycles $\left(94^{\circ} \mathrm{C}\right.$ for $1 \mathrm{~min}, 57^{\circ} \mathrm{C}$ for $30 \mathrm{~s}, 72^{\circ} \mathrm{C}$ for $\left.1 \mathrm{~min}\right)$; one cycle $\left(94^{\circ} \mathrm{C}\right.$ for $1 \mathrm{~min}, 57^{\circ} \mathrm{C}$ for $30 \mathrm{~s}, 72^{\circ} \mathrm{C}$ for $10 \mathrm{~min}$ ). The size of amplicons was confirmed by electrophoresis on a $2.5 \%$ agarose gel, visualised after staining with ethidium bromide.

DGGE was performed on a C.B.S. Scientific ${ }^{\circledR}$ system (C. B. S. Scientific Company, Inc., Del Mar, CA, USA). Gels contained 30 to $50 \%$ denaturant gradient in $8 \%$ acrylamide gels and were run at $130 \mathrm{~V}, 200 \mathrm{~mA}, 250 \mathrm{~W}$ for $16 \mathrm{~h}$ at $60^{\circ} \mathrm{C}$. DNA was visualised by $\mathrm{Ag}$ staining with a commercial DNA Silver Staining Kit (Amersham Biosciences, Uppsala, Sweden). Gels were scanned using a GS-800 Calibrated Imaging Densitometer (Bio-Rad, Laboratories Ltd, Hemel Hempstead, Herts, UK). Scanned DGGE images were analysed with Quantity One ${ }^{\circledR}$ Software (Bio-Rad) by scoring for the presence or absence of bands at different positions in each lane. Two different DGGE gels were run; one including samples from animals 90, 91 and 92 (periods 1 and 2) and another from animals 93, 94 and 95 (periods 1 and 2). DGGE profiles of rumen and duodenal samples within the same gels were compared by using similarity trees. Each band position present in the gel was binary coded for its presence or absence within a lane and each lane was compared by using a similarity matrix (Regensbogenova et al. 2004). Trees were constructed by using the NEIGHBOUR program (PHYLIP (Phylogeny Inference Package) version 3.6a; F. Felsentein, University of Washington, Seattle, WA, USA).

\section{Real-time polymerase chain reaction assay}

Protozoal rDNA concentration was determined using a realtime PCR assay developed by Sylvester et al. (2004, 2005) in duodenal samples, using ciliate-specific primers: forward $-5^{\prime}$ GCTTTCGWTGGTAGTGTATT- $3^{\prime}$-, reverse $-5^{\prime}$-CTTGCCCTCYAATCGTWCT3' - . Three replicate extractions of DNA were performed on each sample and three replicates of the pooled DNA extracts were used. A no-template (sterile distilled water) negative control was loaded on each plate run to screen for possible contamination and dimmer formation and to set the background fluorescence for plate normalisation. The extracted DNA from washed protozoal solutions from each animal, after DNA quantification, was diluted to generate the necessary standard curves. Real-time PCR was performed using a DNA Engine Opticon ${ }^{\circledR}$ System, PTC-200 DNA Engine ${ }^{\mathrm{TM}}$ Cycler (MJ Research (now BioRad)). DNA extract $(1 \mu \mathrm{l})$ was added to amplification reactions $(50 \mu \mathrm{l})$ containing $50 \mathrm{pmol}$ of each primer, $25 \mu \mathrm{l}$ of SYBR $^{\circledR}$ Green JumpStart ${ }^{\text {TM }}$ Taq ReadyMix ${ }^{\text {TM }}$ (Sigma, Poole, Dorset, UK) containing $20 \mathrm{~mm}$-tri(hydroxymethyl)-aminomethane- $\mathrm{HCl}(\mathrm{pH} 8.3), 100 \mathrm{~mm}-\mathrm{KCl}, 7 \mathrm{~mm}-\mathrm{MgCl}_{2}, 0.4 \mathrm{~mm}$ each dNTP, stabilisers, 0.05 unit/ $\mu$ T Taq DNA Polymerase, JumpStart Taq, antibody, and SYBR Green I. Cycling conditions were $94^{\circ} \mathrm{C}$ for $4 \mathrm{~min}$; forty-five cycles of $94^{\circ} \mathrm{C}$ for $30 \mathrm{~s}, 54^{\circ} \mathrm{C}$ for $30 \mathrm{~s}, 72^{\circ} \mathrm{C}$ for $1 \mathrm{~min}$; and a final extension of $72^{\circ} \mathrm{C}$ for $6 \mathrm{~min}$. Fluorescence readings were taken after each extension step, and a final melting analysis was obtained by slow heating with $0 \cdot 1^{\circ} \mathrm{C} / \mathrm{s}$ increment from 65 to $95^{\circ} \mathrm{C}$, with fluorescence collection at $0 \cdot 1^{\circ} \mathrm{C}$ intervals. The threshold cycle (i.e. the amplification cycle in which product formation exceeds background fluorescence) of each standard dilution was determined during the exponential phase of amplification and regressed against the logarithm (base 10) of known protozoal DNA standards that had been prepared for each animal. All post-run data analyses were performed using MJ Research Opticon Monitor Software (version 1.06).

Total bacterial rDNA concentration, as an index of bacterial contamination, in concentrated protozoal solutions obtained after each filtration step was measured by real-time PCR using the primers designed by Maeda et al. (2003) to target $16 \mathrm{~S}$ rDNA: forward 5'-GTGSTGCAYGGYTGTCGTCA-3'; reverse 5'-ACGTCRTCCMCACCTTCCTC- $3^{\prime}$. DNA extract $(1 \mu \mathrm{l})$ was added to amplification reactions $(50 \mu \mathrm{l})$, containing 20 pmol of each primer, $25 \mu$ l of SYBR ${ }^{\circledR}$ Green JumpStart ${ }^{\mathrm{TM}}$ Taq ReadyMix ${ }^{\text {TM }}$ (Sigma) containing $20 \mathrm{~mm}$-tri(hydroxymethyl)-aminomethane- $\mathrm{HCl}(\mathrm{pH} \quad 8.3), 100 \mathrm{~mm}-\mathrm{KCl}, 7 \mathrm{~mm}-$ $\mathrm{MgCl}_{2}, 0.4 \mathrm{mM}$ each dNTP, stabilisers, 0.05 unit $/ \mu \mathrm{l}$ Taq DNA Polymerase, JumpStart Taq, antibody, and SYBR Green I. Cycling conditions were $95^{\circ} \mathrm{C}$ for $5 \mathrm{~min}$, forty cycles of $95^{\circ} \mathrm{C}$ for $15 \mathrm{~s}, 61^{\circ} \mathrm{C}$ for $1 \mathrm{~min}$ and $72^{\circ} \mathrm{C}$ for $30 \mathrm{~s}$. Fluorescence readings, melting analysis and standard analyses were performed as described earlier for the protozoal assay. A bacterial rDNA standard curve was generated from DNA extracted from a mix (equal volumes) of $24 \mathrm{~h}$ cultures of the following rumen bacterial strains all grown on Hobson's medium 2 (Stewart et al. 1997): Prevotella ruminicola 23, Butyrivibrio fibrisolvens SH13, Ruminococcus albus SY3, Prevotella albensis M384, Clostridium sticklandii 12662, Peptostreptococcus anaerobius 27337 , Ruminococcus flavefaciens Fd1, Mitsuokella multiacidus 46/5, Selenomonas ruminantium 2388, Lachnospira multipara D15d, Veillonela parvula L59, Prevotella bryantii B14, Prevotella brevis GA33, Lactobacillus casei LB17, Clostridium aminophilum 49906, Streptococcus bovis ES1 and Megasphera elsdenii $\mathrm{J} 1$, all obtained from the Rowett Research Institute (Aberdeen, UK) culture collection.

\section{Chemical analysis}

Water-soluble carbohydrate in silage was determined spectrophotometrically using anthrone in sulfuric acid on a Technicon AutoAnalyzer (Technicon Corporation, Tarrytown, NY, USA; Thomas, 1977). Ash was analysed by combusting the ground samples at $550^{\circ} \mathrm{C}$ for $6 \mathrm{~h}$ in a muffle furnace and organic matter content was calculated by mass difference. Total $\mathrm{N}$ was determined by a micro-Kjeldahl technique using 'kjeltec' equipment (Perstorp Analytical Ltd, Maidenhead, Berks, UK). Neutral-detergent fibre was determined as described by Van Soest et al. (1991) and acid-detergent fibre was analysed according to the method of Van Soest \& Wine (1967) using a Tecator Fibretec System (Tecator Ltd, Thornbury, Bristol, $\mathrm{UK})$. $\mathrm{Cr}$ and $\mathrm{Yb}$ concentrations of digesta and infusate solutions were determined using a Pye Unicorn SP9 atomic absorption spectrophotometer (Unicam, Cambridge, Cambs, UK) as described by Williams et al. (1962). Purine bases were used as total microbial markers and were determined 
in duodenal fractions and microbial pellets obtained from the rumen using the HPLC as described by Cozzi et al. (1993).

Fatty acids in freeze-dried duodenal digesta and ruminal protozoa samples were extracted and methylated following the procedure of Kramer \& Zhou (2001). Briefly, $300 \mathrm{mg}$ dried digesta was placed in $15 \mathrm{ml}$ tubes with Teflon-lined screw caps, followed by the addition of $100 \mu l$ methyl heneicosanoate $(15 \mathrm{mg} / \mathrm{ml})(21: 0$, internal standard $)$ and $5 \mathrm{ml}$ of a 2:1 mixture of chloroform and methanol. The sample was vortexed for $5 \mathrm{~min}$ and centrifuged at $900 \mathrm{~g}$ for $5 \mathrm{~min}$. The top layer was aspirated and placed in a new tube. The original sample was extracted twice more with $5 \mathrm{ml}$ chloroformmethanol. The lipid extract in chloroform-methanol was dried under $\mathrm{N}_{2}$ in a water-bath at $50^{\circ} \mathrm{C}$ and re-dissolved in $1 \mathrm{ml}$ hexane. Then, $3 \mathrm{ml}$ of $0.5 \mathrm{~N}-\mathrm{NaOH}$ in methanol was added, vortexed and heated for $15 \mathrm{~min}$ at $50^{\circ} \mathrm{C}$. Another $3 \mathrm{ml}$ of $5 \% \mathrm{HCl}$ in methanol was added, vortexed and heated for $60 \mathrm{~min}$ at $50^{\circ} \mathrm{C}$. After saponification and methylation, methyl esters of fatty acids were recovered in $5 \mathrm{ml}$ hexane and quantified by GC on a CP-Select chemically bonded for a fatty acid methyl ester (FAME) column $(100 \mathrm{~m} \times 0.25 \mathrm{~mm}$ internal diameter; Varian Inc., Palo Alto, CA, USA) with ultra-highpurity $\mathrm{He}$ carrier gas at a flow rate of $7 \mathrm{ml} / \mathrm{min}$. Injector and detector temperatures were $250^{\circ} \mathrm{C}$ and $255^{\circ} \mathrm{C}$, respectively. The splitting ratio to the flame ionisation detector was $1: 80$. The oven temperature schedule was: $70^{\circ} \mathrm{C}$ for $1 \mathrm{~min}$; increase to $100^{\circ} \mathrm{C}$ at $5^{\circ} \mathrm{C} / \mathrm{min}$; constant $100^{\circ} \mathrm{C}$ for $2 \mathrm{~min}$; increase to $175^{\circ} \mathrm{C}$ at $10^{\circ} \mathrm{C} / \mathrm{min}$; constant $175^{\circ} \mathrm{C}$ for $34 \mathrm{~min}$; increase to $225^{\circ} \mathrm{C}$ at $4^{\circ} \mathrm{C} / \mathrm{min}$; constant $225^{\circ} \mathrm{C}$ for $22 \mathrm{~min}$. The total run time was $85 \mathrm{~min}$. Individual fatty acids were quantified by reference to the internal standard and using external standards: $c 9, t 11-C L A ; t 10, c 12-C L A ; t 11-18: 1$ (Matreya, Pleasant Gap, PA, USA) and a standard Supelco 37 component FAME mixture (Supelco, Poole, Dorset, UK).

\section{Calculation and statistical analysis}

Digesta flows were calculated after mathematical reconstitution of true digesta as described by Faichney (1975). Microbial $\mathrm{N}$ flow to the duodenum was computed by taking into account the purine: $\mathrm{N}$ ratio calculated in the microbial pellets from the rumen and in the duodenal samples.

The N:total DNA ratios and the N:individual fatty acid ratios were recorded for the concentrated protozoal standard for every experimental animal, and the duodenal flows of protozoal DNA, N and individual fatty acids were calculated.

Data were subjected to ANOVA fitted with orthogonal polynomials (Genstat 7; Lawes Agricultural Trust, Rothamsted, Herts, UK) with diet as the treatment effect and blocking for period and animal.

\section{Results}

The chemical composition of the silages is given in Table 1 . The composition of the silages was typical of well-preserved grass silage and very similar between the HS and CS, although the HS contained slightly higher $\mathrm{N}$ and diethyl ether extract contents and lower neutral-detergent fibre content than the CS. Water-soluble carbohydrate content of the HS $(739 \mathrm{~g} / \mathrm{kg}$ DM) was $27 \%$ higher than in the CS $(581 \mathrm{~g} / \mathrm{kg}$ DM). Fatty acid composition was similar between the HS and CS.
Table 1. Chemical composition ( $\mathrm{g} / \mathrm{kg} \mathrm{DM})$ and fatty acid profile of the experimental diets: control silage (CS) or high-water-soluble carbohydrates silage (HS)

\begin{tabular}{lcc}
\hline & CS & HS \\
\hline DM & 416 & 380 \\
Crude protein & 153 & 169 \\
Acid-detergent fibre & 379 & 363 \\
Neutral-detergent fibre & 622 & 585 \\
Diethyl ether extract & 21 & 33 \\
Water-soluble carbohydrates & 58 & 74 \\
Fatty acid composition (g/kg DM) & & \\
$12: 0$ (Myristic) & 0.06 & 0.10 \\
$14: 0$ (Lauric) & 0.58 & 0.64 \\
$16: 0$ (Palmitic) & $4 \cdot 25$ & 3.89 \\
$16: 1$ (Palmitoleic) & $0 \cdot 12$ & 0.07 \\
$18: 0$ (Stearic) & 0.56 & 0.44 \\
$18: 1 n$-9 (Oleic) & 0.62 & 0.57 \\
$18: 2 n$-6 (Linoleic) & $4 \cdot 21$ & 3.89 \\
$18: 3 n$-3 (Linolenic) & $9 \cdot 21$ & 10.2 \\
$20: 0$ (Arachidic) & 0.22 & 0.17 \\
Total fatty acids & 20.4 & $20 \cdot 8$ \\
\hline
\end{tabular}

Comparative denaturing gradient gel electrophoresis banding profiles and bacterial contamination of washed protozoal standards

The DGGE banding profiles were generally more similar between the ruminal and duodenal samples within each animal than when compared between sampling sites across animals as shown by the phylogenetic tree obtained after unweighted pair-group method using arithmetic averages (UPGMA) cluster analysis (Fig. 1). The set of primers used produced twenty-one major different bands. Every band obtained from a ruminal sample was also found in the corresponding duodenal sample from the same animal, showing the same protozoal species distribution in rumen and duodenal samples.

Bacterial DNA contribution to total DNA decreased from $53.7 \%$ in strained rumen fluid filtered through $400 \mu \mathrm{m}$ poresize nylon cloth to $7.4 \%$ after the third filtration-washing on a $10 \mu \mathrm{m}$ pore-size nylon cloth and remained constant after further washing. The washed protozoal standard obtained from animal 90 in period 1 showed a high bacterial DNA content, which accounted for $39 \%$ of the total DNA even after repeated washing on a $10 \mu \mathrm{m}$ pore-size nylon cloth. Data from this animal in period 1 were thus excluded from all analysis. For the rest of the animals every band found in the rumen was also detected in the protozoal standards, as shown in Fig. 2 for animal 91 fed the HS diet.

\section{Protozoal counts and fatty acid content of rumen protozoa}

Concentrations and distribution of ciliates based on visual counts are shown in Table 2. Animals offered the HS $\left(13.2 \times 10^{5} \mathrm{cell} / \mathrm{ml}\right)$ diet had higher $(P<0.05)$ total protozoa counts compared with those fed the CS $\left(8.12 \times 10^{5}\right.$ cell $\left./ \mathrm{ml}\right)$ diet. Entodinium sp. were the predominant protozoa found in the rumen of all animals and accounted for 60 and $65 \%$ of the total protozoa, respectively, for the CS and HS diets. Holotrich protozoa (Isotrichidae) only appeared in the rumen fluid of animals offered the HS diet, accounting for $1.5 \%$ of the total protozoa. 

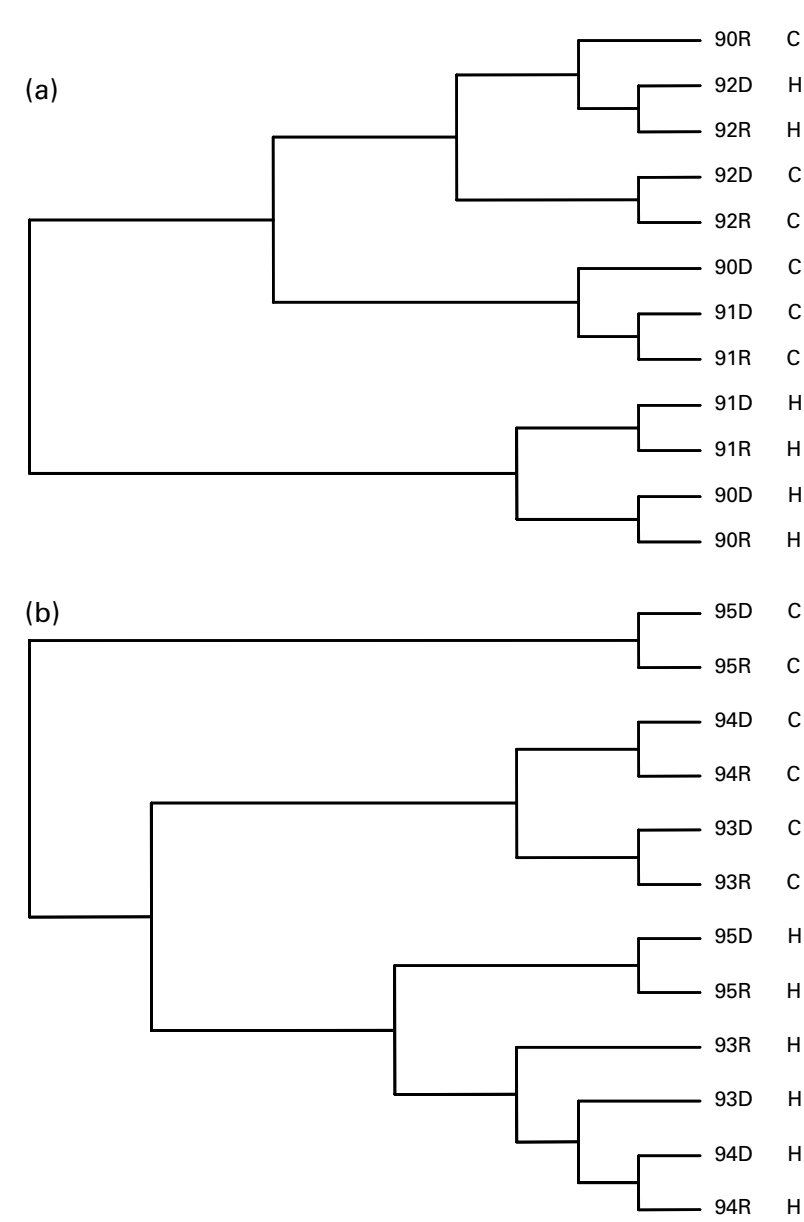

Fig. 1. Dendrograms derived after unweighted pair-group method using arithmetic averages (UPGMA) cluster analysis of denaturing gradient gel electrophoresis banding profiles of rumen (R) and duodenal (D) samples in animals 90, 91 and 92 (a) and 93, 94 and 95 (b) fed either control (C) or high-watersoluble carbohydrates $(\mathrm{H})$ silages.

The fatty acid composition of washed protozoal suspensions is also shown in Table 2. Stearic acid (18:0) was the most abundant fatty acid, followed by palmitic acid (16:0), giving 16:0:18:0 ratios of $0 \cdot 72$ and 0.85 , respectively for the CS and HS diets. VA content was slightly lower than $c 9, c 12-18: 2$ content at 8.73 to $12.2 \%$ of the total fatty acids. The content of the $c 9, t 11$-CLA isomer was 5.66 and $4.95 \mu \mathrm{g} / \mathrm{mg} \mathrm{N}$, respectively, for the CS and HS diets, three times higher than the other measured CLA isomer $(t 10, c 12)$. The content of all fatty acids did not differ $(P>0 \cdot 05)$ between diets, with the exception of $15: 0$, which was higher $(P<0 \cdot 05)$ in the HS diet. Linolenic acid $(18: 3)$ was found in protozoal standards at lower concentrations than $c 9, c 12-18: 2$ and $18: 0$.

\section{Duodenal flows}

Table 3 shows DM, organic matter and $\mathrm{N}$ intakes and duodenal flows. There were no diet effects on intakes or flows. However, microbial $\mathrm{N}$ flow tended to be higher $(P=0.154)$ in animals fed the HS v. CS diet $(73.8 v .67 .8 \mathrm{~g} / \mathrm{d}$, respectively). Estimated duodenal flow of protozoal $\mathrm{N}$ was 14.2 and $18.2 \mathrm{~g} / \mathrm{d}$ for animals fed the CS and HS, respectively $(P>0 \cdot 05)$. They
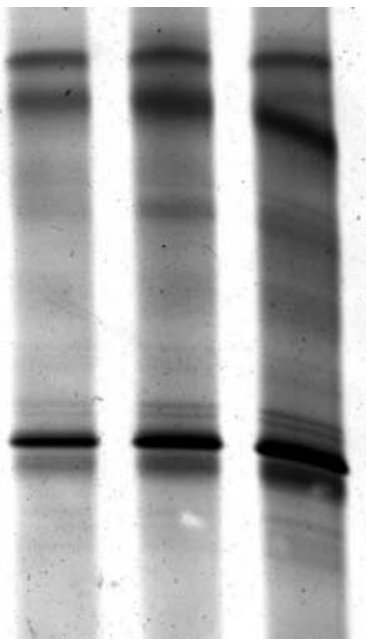

Fig. 2. Comparative protozoal banding profile between duodenal (D) and ruminal $(R)$ samples and a protozoal standard solution $(P)$ in animal 91 fed the high-water-soluble carbohydrates silage diet.

represented, respectively, $12 \cdot 3$ and $15.4 \%$ of total $\mathrm{N}$ and 21 and $24.7 \%$ of microbial $\mathrm{N}$ flowing to the duodenum.

Duodenal flows $(\mathrm{g} / \mathrm{d})$ of long-chain fatty acids and biohydrogenation intermediates are shown in Table 4. Fatty acid profiles in duodenal digesta reflected the long-chain fatty acid profiles found in the silage and the biohydrogenation process that takes place in the rumen; higher contents of $\mathrm{C}_{18}$ than $\mathrm{C}_{16}$ and the majority of $\mathrm{C}_{18}$ fatty acids in the form of stearic acid. In agreement with dietary concentrations, long-chain fatty acid flow did not differ $(P>0.05)$ between experimental diets.

The protozoal contribution to total fatty acids flowing to the duodenum varied depending on the fatty acid considered. As a general pattern, protozoal contribution appears to be higher for

Table 2. Protozoa counts and type distribution (\%) and composition of protozoal standard solutions in the rumen of steers offered control silage (CS) or high-water-soluble carbohydrates silage (HS)

(Mean values and standard errors of the difference)

\begin{tabular}{lcccc}
\hline & CS & HS & SED & $P$ \\
\hline Total protozoa $\left(\times 10^{5} / \mathrm{ml}\right)$ & $8 \cdot 12$ & 13.2 & 1.26 & 0.025 \\
Entodiniinae & $60 \cdot 1$ & 65.4 & & \\
Diplodiniinae & 37.8 & 31.5 & & \\
Diplodinium & 40.9 & 54.1 & & \\
Eudiplodinium & $55 \cdot 8$ & 45.9 & & \\
Ophryscolecinae & $2 \cdot 1$ & 1.6 & & \\
Isotrichidae & 0 & 1.5 & & \\
Protozoal standards & & & & \\
N $(\mathrm{g} / \mathrm{ml})$ & 0.17 & 0.21 & 0.012 & 0.586 \\
DNA:N $(\mu \mathrm{g} / \mathrm{mg})$ & 34.3 & 27.7 & 1.238 & 0.725 \\
Fatty acids $(\mu \mathrm{g} / \mathrm{mg} \mathrm{N})$ & & & & \\
$14: 0$ & 8.62 & 9.93 & 2.3 & 0.931 \\
$15: 0$ & 1.76 & 3.71 & 0.4 & 0.014 \\
$16: 0$ & 243 & 235 & 56.4 & 0.826 \\
$17: 0$ & 1.54 & 2.54 & 0.7 & 0.246 \\
$18: 0$ & 338 & 278 & 142.7 & 0.503 \\
Trans-11-18:1 & 81.0 & 72.0 & 15.0 & 0.999 \\
Cis-9, cis-12-18:2 & 106 & 107 & 1.42 & 0.943 \\
$18: 3$ & 53.6 & 52.2 & 5.49 & 0.157 \\
Cis-9, trans-11-CLA & 5.66 & 4.95 & 2.59 & 0.644 \\
Trans-10, cis-12-CLA & 1.96 & 1.95 & 6.09 & 0.989 \\
\hline
\end{tabular}

CLA, conjugated linoleic acid. 
Table 3. Daily intakes and duodenal flows of dry matter, organic matter (OM) and nitrogen and rumen protozoa in steers fed control silage (CS) or high-water-soluble carbohydrates silage (HS)

(Mean values and standard errors of the difference)

\begin{tabular}{lcccc}
\hline & CS & HS & SED & $P$ \\
\hline Intakes & & & & \\
$\quad$ DM $(\mathrm{kg} / \mathrm{d})$ & 3.54 & 3.53 & 0.021 & 0.944 \\
OM $(\mathrm{kg} / \mathrm{d})$ & 3.29 & 3.28 & 0.027 & 0.952 \\
$\mathrm{~N}(\mathrm{~g} / \mathrm{d})$ & 111 & 114 & 0.001 & 0.303 \\
Flows & & & & \\
DM $(\mathrm{kg} / \mathrm{d})$ & 2.68 & 2.75 & 0.562 & 0.245 \\
OM $(\mathrm{kg} / \mathrm{d})$ & 1.94 & 1.97 & 0.028 & 0.622 \\
Total N (g/d) & 115 & 118 & 0.857 & 0.611 \\
Microbial N (g/d) & 67.5 & 73.8 & 0.432 & 0.154 \\
Protozoal N (g/d) & 14.2 & 18.2 & 0.502 & 0.058 \\
& & & &
\end{tabular}

unsaturated compared with saturated fatty acids. Protozoa were responsible for between 36 to $39 \%$ of $c 9, t 11$-CLA flow, 48 to $64 \%$ of the $t 10, c 12$-CLA flow and 39 to $40 \%$ of the VA flow but no more than $10 \%$ of $18: 0$ and $20 \%$ of $16: 0$ flows

\section{Discussion}

\section{Measuring duodenal flow of protozoa}

By comparing the protozoal DGGE banding profile obtained with specific protozoa $18 \mathrm{~s}$ RNA primers between rumen fluid, duodenal digesta and washed protozoal standards we found no evidence of selective protozoal loss during protozoa isolation nor through digesta passage to the duodenum (Fig. 2), which confirms the suitability of the protozoa standards to represent the whole protozoal population in the rumen. Thus, accepting that some errors may remain because of differences in the relative numbers of different protozoal groups between the fractions as indicated by differences in the intensities of bands on the DGGE gels, in the present study we have used washed protozoal suspensions obtained by filtration as standards for real-time PCR quantification of protozoal flow to the duodenum and for fatty acid profiling within cells. Quantification as to what if any errors in our calculations will result from a change in the relative distribution of different protozoal groups in different fractions will require a more detailed knowledge of the fatty acid composition of individual protozoal species plus the development of specific primer set to quantify individual protozoal species in digest samples. However, based on a semi-quantitative examination of band intensities in our DGGE profiles we estimate that there was no more than a $9.2 \%$ difference in the relative distribution of total ciliate biomass between bands in profiles of rumen compared with duodenal samples from the same animal, suggesting the resultant error might also be small.

Given the significant contribution of protozoa to the total microbial protein in the rumen, their important role in bacteria predation and their high recycling rates, several methods have been used to estimate the protozoal flow leaving the rumen (Steinhour et al. 1982; Michalowski et al. 1986; Punia et al. 1992; Dijkstra, 1994; Shabi et al. 2000). As noted previously, research in this area is hindered by the lack of an accurate

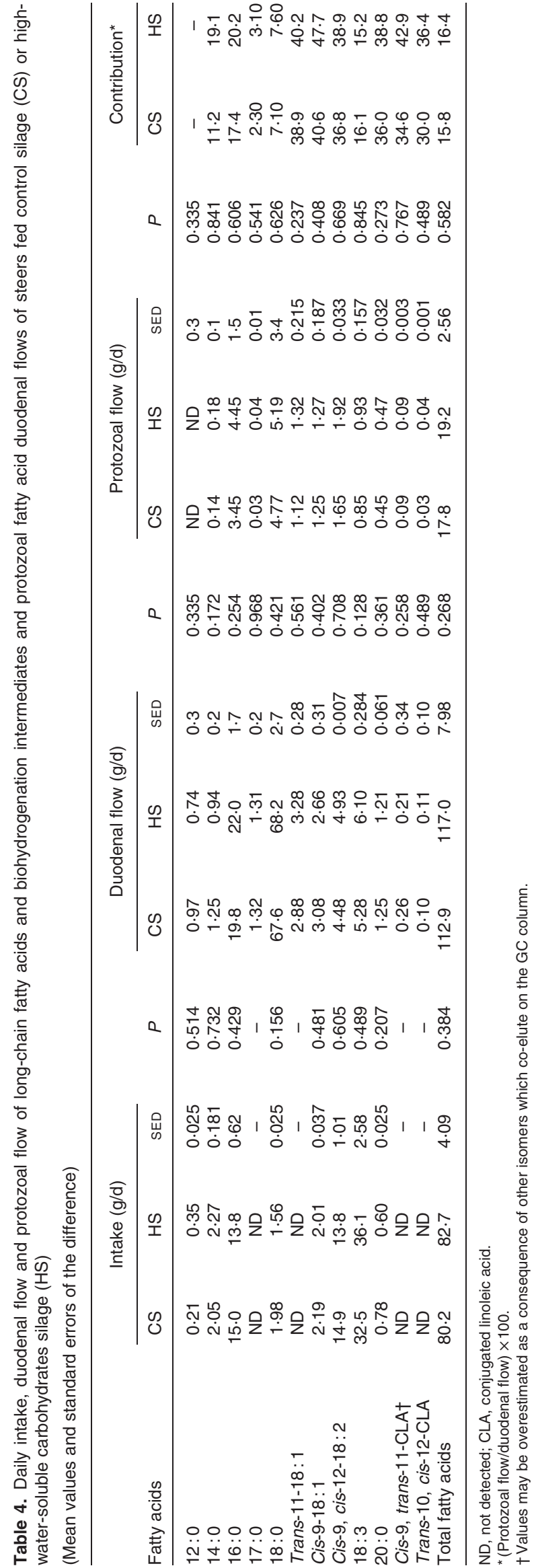


protozoal marker (Firkins et al. 1998). Recent developments in molecular techniques to allow the assessment of the diversity, population dynamics and community composition (Karnati et al. 2003), combined with real-time PCR assays developed to quantify copies of the genes encoding protozoal $18 \mathrm{~S}$ rRNA, offer a novel approach to quantifying protozoal flow to the duodenum (Sylvester et al. 2004, 2005). Using the approach of Sylvester in the present study we estimate duodenal daily flows of protozoal $\mathrm{N}$ of 14 and $18 \mathrm{~g}$ for animals fed the CS and HS, respectively, which is in the same range $(13-17 \mathrm{~g} / \mathrm{d})$ reported by Punia et al. (1992) in steers with a similar live weight. The present data indicate that protozoal cells make up $21-25 \%$ of total microbial $\mathrm{N}$ flowing to the duodenum. The contribution of protozoal $\mathrm{N}$ to total rumen microbial $\mathrm{N}$ on various diets has been estimated to range from 20 to $80 \%$ (Coleman, 1979), the highest values being obtained with high-grain diets. The values for the protozoal contribution to total microbial $\mathrm{N}$ flow from the rumen reported in the present study are in the same range as those reported by Punia et al. (1992) (15-19\%), Dijkstra et al. (1998) (22\%) and Reynal et al. (2003) (19-29\%) using different approaches and experimental diets.

\section{Fatty acid composition of rumen protozoa}

Determining the fatty acid composition of rumen protozoa is complicated by the technical difficulties involved in obtaining protozoal preparations uncontaminated by bacteria and feed particles and because of the variation in protozoal populations between individual animals and experimental diets.

In the present study we used $16 \mathrm{~S}$ rDNA quantified by realtime PCR as a marker of bacterial contamination of our protozoal samples during the successive washes and filtrations.

The levels of contamination achieved $(7.4 \%)$ during protozoal isolation compares favourably with values obtained by others (23\%; Volden et al. 1999). Thus we conclude that our washed protozoal standards contained only bacterial material within or strongly bound to the surface of the protozoal cells which would in effect leave the rumen as part of the protozoal pool. Additionally, it is well established that the diet fed to animals determines the profile of the major long-chain fatty acids in ruminal micro-organisms, so that the $\mathrm{C}_{16}: \mathrm{C}_{18}$ ratio in the diet will be reflected in the ruminal digesta (Cook et al. 1972). Thus, in terms of the $C_{16}: C_{18}$ ratio and the extent to which unsaturated $\mathrm{C}_{18}$ fatty acids have been hydrogenated to $18: 0$, our measurements found a higher $\mathrm{C}_{18}: \mathrm{C}_{16}$ ratio than previously reported (Devillard et al. 2004), possibly reflecting the dietary fatty acid profile found in the experimental silage. However, not only the fatty acid content of the diet drives the fatty acid profile in the protozoal fraction. Our DGGE results show different protozoal diversity present in the rumen of different animals fed the same diet. Chalupa \& Kutches (1968) found no hydrogenation of $\left[1-{ }^{14} \mathrm{C}\right]$ linoleic and $\left[1-{ }^{14} \mathrm{C}\right]$ oleic acids by Holotrich protozoa cultivated in vitro, while in the same experiment they observed that Entodiniomorphid protozoa were capable of hydrogenating the same fatty acids. Therefore, difference in the protozoal distribution might also explain different fatty acid profiles. In the present study, Holotrich protozoa were only found in those animals fed the HS diet, possibly reflecting the preference of these protozoa for the use of soluble carbohydrates (Williams \& Coleman, 1992). It is possible that the different proportions of protozoal types observed between the two experimental diets via the presence or absence of Holotrichs could help explain the different fatty acid composition of the protozoal population isolated from animals fed the two experimental diets used in the present study compared with the study of Devillard et al. (2004). In agreement with the present study, Devillard et al. (2004) observed higher concentrations of VA than CLA $(c 9, t 11$ isomer) in the ciliates. They also reported a higher VA content in protozoa than in bacteria.

Devillard et al. (2004) did not speculate on the reasons for the high VA content of rumen protozoa. One theoretical mechanism could be the de novo synthesis of $\mathrm{C}_{18}$ long-chain fatty acids and subsequent desaturation to $18: 1$. Emmanuel (1974) observed net incorporation of radioactive SCFA into octadecanoic acid with the double bounds in the $\Delta^{11}$ position compared with oleic acid $\left(\Delta^{9}\right)$, suggesting the above mechanism may operate. However, the possibility of rumen protozoa producing $18: 2$ isomers via desaturation has not yet been examined.

Protozoa rapidly engulf chloroplasts released from plant cells (Hall et al. 1974) and possibly as a result the fatty acids of rumen protozoa are less saturated (between 22 and $35 \%$ of the fatty acids present as $18: 1,18: 2$ or $18: 3$ ) compared with bacteria (between 7 and $25 \%$ of the fatty acids present as $18: 1,18: 2$ or $18: 3$ ) (Harfoot \& Hazlewood, 1997). Given that protozoa make up approximately half the rumen biomass (Jouany, 1995), this suggests that ciliate protozoa represent a major pool of unsaturated fatty acids in the rumen.

The capacity of protozoa to store fatty acids is unknown and it is believed to differ between different types of protozoa. The presence of particulate matter and its capacity to bind NEFA should affect the maximal fatty acid concentration achieved in the in vitro media (Harfoot et al. 1973; Girard \& Hawke, 1978). It might be speculated that the capacity of protozoa to store fatty acids depends on the combination of factors: rate of incorporation of NEFA to cellular lipids; presence of particulate matter; symbiotic relationship with rumen bacteria; rate of hydrogenation of unsaturated fatty acids. These factors are of crucial importance, as unsaturated fatty acids appear to be partially protected from biohydrogenation by their incorporation into microbial phospholipids.

\section{Protozoal contribution to vaccenic acid and conjugated linoleic acid supply from the rumen}

The present study is the first to attempt to quantify the contribution of protozoa to the fatty acid flow reaching the duodenum. We conclude that protozoa contribute to almost $40 \%$ of the $c 9, t 11$-CLA and 30 to $36 \%$ of the $t 10, c 9$-CLA isomer flow and, more importantly, that $40 \%$ of the VA leaving the rumen does so in ciliate protozoa. Given that the two silage diets used were very similar in chemical composition, it would be interesting to confirm the protozoa contributions on diets high in concentrate that increased the proportion of Holotrichs in the rumen. It is interesting to speculate on the effect that the presence or absence of protozoa in the rumen would have on the CLA content of ruminant products. On initial observation, the present results suggest that defaunation would reduce CLA concentrations; however, other studies on the effect of defaunation on lipid metabolism in the rumen are 
contradictory. While rumen protozoa are known to hydrogenate lipids, the biohydrogenation activity of rumen contents was only slightly reduced by defaunation (Dawson \& Kempt, 1969). Klopfenstein et al. (1966) reported a decrease in $18: 1$ in blood in the absence of protozoa, which is not consistent with protozoa being a major irreplaceable source of $18: 1$ supply to the small intestine. More recently, Jouany \& Lassalas (2004) failed to find any significant difference in fatty acid metabolism and CLA synthesis between rumen fluid collected from faunated and non-faunated animals. However, they did find significant differences between short- (2 months) and long-term (12 months) defaunated animals suggesting that different bacterial populations developed in the two different defaunated groups. Ozutsumi et al. (2005) observed significantly different bacterial communities in faunated and defaunated cattle by using $16 \mathrm{~S}$ rDNA clone libraries, which suggests that the comparison between ciliate-free and faunated animals should be interpreted carefully, as bacterial metabolic activities would also change.

In conclusion, a significant proportion of the CLA and VA leaving the rumen do so in protozoal cells. Several reasons could explain the high CLA and VA content of rumen protozoa, although none have been proven yet. Given that protozoa populations vary considerably even between animals receiving the same diet and that they can be affected by certain additives it would seem necessary to re-investigate the role of protozoa in fatty acid biohydrogenation in the rumen.

\section{Acknowledgements}

The authors would like to acknowledge expert analytical advice from M. R. F. Lee and J. Tweed. D. R. Y.-R. gratefully acknowledges the receipt of a research contract from the European Commission (Marie Curie Program, RUMENOMICS 010972).

\section{References}

Abaza MA, Abou Akkada AR \& El Shazly K (1975) Effect of rumen protozoa on dietary lipid in sheep. J Agric Sci 85, 135-143.

Bauman DEL, Baumgard BA, Corl BA \& Griinari JM (1999) Biosynthesis of conjugated linoleic acids in ruminants. Proc Am Soc Anim Sci. Accesssed June 2002. http://www.asas.org/jas/symposia/ proceedings/0937.pdf

Blankson H, Stakkestad JA, Fagertun H, Thom E, Wadstein J \& Gudmundsen O (2000) Conjugated linoleic acid reduces body fat mass in overweight and obese humans. J Nutr 130, 2943-2948.

Chalupa A \& Kutches AJ (1968) Biohydrogenation of linoleic 1-C14 acid by rumen protozoa. J Anim Sci 27, 1502-1508.

Coleman GS (1979) The role of rumen protozoa in the metabolism of ruminants given tropical feed. Trop Anim Prod 4, 199-213.

Cook LJ, Scott TW, Faichney GJ \& Davies HL (1972) Fatty acid interrelationships in plasma, liver, muscle and adipose tissues of cattle fed safflower oil protected from ruminal hydrogenation. Lipids 7, 83-89.

Cozzi G, Bittante G \& Polan CE (1993) Comparison of fibrous materials as modifiers of in-situ ruminal degradation of corn gluten meal. J Dairy Sci 76, 1106-1113.

Dawson RMC \& Kemp P (1969) The effect of defaunation on the phospholipids and on the hydrogenation of unsaturated fatty acids in the rumen. Biochem $J$ 115, 351-352.

De la Torre A, Debiton E, Durand D, Chardigny JM, Berdeaux O, Loreau O, Barthomeuf C, Bauchart D \& Gruffat D (2005)
Conjugated linoleic acid isomers and their conjugated derivatives inhibit growth of human cancer cell lines. Anticancer Res 25, 3943-3949.

Dehority BA (1984) Evaluation of subsampling and fixation procedures used for counting rumen protozoa. Appl Environ Microbiol 48, 182-185.

Dehority BA (2003) Rumen Microbiology. Nottingham, UK: Nottingham University Press.

Devillard E, McIntosh FM, Castet RJ, Wallace J \& Newbold CJ (2004) Conjugated linleic acid composition of rumen bacterial and protozoal populations. Rep Nutr Develop 44, Suppl. 1, 60.

Dijkstra J (1994) Simulation of the dynamics of protzoa in the rumen. Br J Nutr 72, 679-699.

Dijkstra J, France J \& Davies DR (1998) Different mathematical approaches to estimating microbial protein supply in ruminants. J Dairy Sci 81, 3370-3384.

Emmanuel B (1974) On the origin of rumen protozoan fatty acids. Biochim Biophys Acta 337, 404-413.

Faichney GJ (1975) The use of markers to partition digestion within gastrointestinal tract of ruminants. In Digestion and Metabolism in the Ruminant, pp. 277-291 [IW McDonald and ACI Warner, editors]. University of New England: Armidale, NSW.

Firkins JL, Allen S, Oldick S \& Pierre ST (1998) Modeling ruminal digestibility of carbohydrates and microbial protein flow to the duodenum. J Dairy Sci 81, 3350-3369.

Girard V \& Hawke JC (1978) The role of holotrichs in the metabolism of dietary linoleic acid in the rumen. Biochim Biophys Acta 528, 404-413.

Hall FJ, West J \& Coleman GS (1974) Fine structural studies on the digestion of chloroplasts in the rumen ciliate Entodinium caudatum. Tissue Cell 6, 243-253.

Harfoot GC \& Hazlewood GP (1997) Lipid metabolism in the rumen. In The Rumen Microbial Ecosystem, pp. 383-425 [PN Hobson and CS Stewart, editors]. London: Chapman Hall.

Harfoot GC, Noble RC \& Moore JH (1973b) Food particles as a site for biohydrogenation of unsaturated fatty acids in the rumen. Biochem J 132, 829-832.

Jouany JP (1995) Effect of rumen protozoa on nitrogen utilization by ruminants. J Nutr $1335 \mathrm{~S}-1346 \mathrm{~S}$.

Jouany JP \& Lassalas B (2004) Effect of short-term period (2 months) and long-term period (12 months) of rumen defaunation on CLA synthesis from pure linoleic and linolenic acids. Reprod Nutr Dev 44, Suppl. 1, S63.

Karnati SKR, Yu Z, Sylvester JT, Dehority BA, Morrison M \& Firkins JL (2003) Tehcnical note: Specific PCR amplification of protozoal $18 \mathrm{~S}$ rDNA sequences from DNA extracted from ruminal samples of cows. J Anim Sci 81, 812-815.

Klopfenstein TJ, Purser DB \& Tyznik WJ (1966) Effects of defaunation on feed digestibility, rumen metabolism and blood metabolites. J Anim Sci 25, 765-773.

Kramer JKG \& Zhou JQ (2001) Conjugated linoleic acid and octadecenoic acids: extraction and isolation of lipids. Eur J Lipid Sci Technol 103, 594-600.

Labarca C \& Paigen K (1980) A simple, rapid, and sensitive DNA assay procedure. Anal Biochem 102, 344-352.

Lee MRF, Harris LJ, Moorby JM, Humphreys MO, Theodorou MK, MacRae JC \& Scollan ND (2002) Rumen metabolism and nitrogen flow to the small intestine in steers offered Lolium perenne containing different levels of water-soluble carbohydrates. Anim Sci 74, 587-596.

Maeda H, Fujimoto C, Haruki Y, Maeda T, Kokeguchi S, Petelin M, Arai H, Tanimoto I, Nishimura F \& Takashiba S (2003) Quantitative real-time PCR using TaqMan and SYBR Green for Actinobacillus actinomycetemcomitans, Porphyromonas gingivalis, Prevotella intermedia, tetQ gene and total bacteria. FEMS Immunol Med Microbiol 39, 81-86. 
Michalowski T, Harmeyer J \& Breves G (1986) The passage of protozoa from the reticulo-rumen through the omasum of sheep. $\mathrm{Br} J$ Nutr 56, 625-634.

Moon-van der Staay SY, van Rder Staay GWM, Javorský P, Jouany JP, Michalowski T, Nsabimana E, Macheboeuf D \& Kišidayová S (2002) Diversity of rumen ciliates revealed by 18 S ribosomal DNA analysis. Reprod Nutr Develop 42, Suppl., S76.

Ozutsumi Y, Tajima K, Takenaka A \& Itabashi H (2005) The effect of protozoa on the composition of rumen bacteria in cattle using 16S rRNA gene clone libraries. Biosci Biotechnol Biochem 69, 499-506.

Punia BS, Leibholz J \& Faichney GJ (1992) Rate of production of protozoa in the rumen and the flow of protozoal nitrogen to the duodenum in sheep and cattle given a pelleted diet of lucerne hay and barley. J Agric Sci (Camb) 118, 229-236.

Regensbogenova MP, Pristas P, Javorsky Hackstein JHP, Newbold CJ \& McEwan N (2004) Assesment of ciliates in the sheep rumen by DGGE. Lett Appl Microbiol 39, 144-147.

Reynal SM, Broderick GA, Ahvenjarvi S \& Huhtanen P (2003) Effect of feeding protein supplements of differing degradability on omasal flow of microbial and undegraded protein. J Dairy Sci 86, $1292-1305$.

Shabi Z, Tagari H, Murphy MR, Bruckental I, Mabjeedh SJ, Zamwel S, Celik K \& Arieli A (2000) Partitinoning of amino acids flowing to the abomasum into feed, bacterial, protozoal, and endogenous fractions. J Dairy Sci 83, 2326-2334.

Singh S \& Hawke JC (1979) The in vitro lipolysis and biohydrogenation of monogalactosyldiglycride by whole rumen content and its fractions. J Sci Food Agric 30, 603-612.

Steinhour WD, Stokes MR, Clark JH, Rogers JA, Davis CL \& Nelson DR (1982) Estimation of the proportion of nonammonia-nitrogen reaching the lower gut of the ruminant derived from bacterial and protozoal nitrogen. Br J Nutr 48, 417-431.

Stewart CS, Flint HJ \& Bryant MP (1997) The rumen bacteria. In The Rumen Microbial Ecosystem, pp. 10-72 [PN Hobson and CS Stewart, editors]. London: Chapman Hall.
Sylvester JT, Karnati SK, Yu Z, Morrrison M \& Firkins JL (2004) Development of an assay to quantify ciliate protozoal biomass in cows using real-time PCR. $J$ Nutr 134, 3378-3384.

Sylvester JT, Karnati SK, Yu Z, Newbold CJ \& Firkins JL (2005) Evaluation of a real time PCR assay quantifying the ruminal pool size and duodenal flow of protozoal nitrogen. J Dairy Sci 88, 2083-2095.

Thomas (1977) An automated procedure for the determination of soluble carbohydrates in herbage. J Sci Food Agric 28, 639-642.

Toomey D, Harhen B, Roche HM, Fitzgerald D \& Belton O (2005) Profound resolution of early atherosclerosis with conjugated linoleic acid. Atherosclerosis 187, 40-49.

Van Soest PJ, Robertson JB \& Lewis BA (1991) Methods for dietary fiber, neutral detergent fiber and non starch polysaccharides in relation to animal nutrition. $J$ Dairy Sci $\mathbf{7 4}$, $3583-3597$.

Van Soest PJ \& Wine RH (1967) Use of detergents in the analysis of fibrous feeds. IV. Determination of plant and cell wall constituents. $J$ Assoc Off Anal Chem 50, 50-55.

Volden HLT, Mydland T \& Harstad OM (1999) Chemical composition of protozoal and bacterial fractions isolated from ruminal contents of dairy cows fed diets differing in nitrogen supplementation. Acta Agric Scand A Anim Sci 49, 235-244.

Wahle KWJ, Steven DH \& Rotondo D (2004) Conjugated linoleic acids: are they beneficial or detrimental to health? Prog Lipid Res 43, 553-587.

Williams AG \& Coleman GS (1992) The Rumen Protozoa. New York: Springer-Verlag.

Williams CHD, David DJ \& Iisma O (1962) The determination of chromic acid oxide in feces samples by atomic absorption spectrophotmetry. J Agric Sci 59, 381-385.

Wright DE (1959) Hydrogenation of lipids by rumen protozoa. Nature 184, 875-876.

Zhang H, Guo Y \& Yuan J (2005) Conjugated linoleic acid enhanced the immune function in broiler chicks. Br J Nutr 94, $746-752$. 